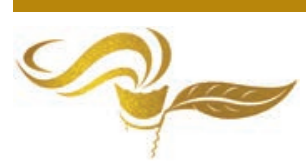

\title{
Impact of COVID-19 in Mexico: A vision
}

\author{
Joel E. Valencia Hernández, Diana M. Sarmiento Páez, Raúl Romero Galindo, \\ David A. Saucedo Alfonzo, Edgar O. López de León, Claudia Hernández Aguilar*
}

Instituto Politécnico Nacional ESIME SEPI, Programa de posgrado en Ingeniería de Sistemas Sistemas Biofísicos Unidad Zacatenco Colonia Lindavista, Ciudad de México, México

* Correspondence: E-mail: clauhaj@yahoo.com; clhernandeza@ipn.mx

Received 17 December, 2020; Revised 8 January, 2021; Accepted 9 January, 2021

Available online 9 January, 2021 at www.atlas-journal.org, doi: 10.22545/2021/00145

\begin{abstract}
rod he current SARS-CoV-2 pandemic is a historical event that has come to change the way of life for humanity; where the population is the main subject of cause and solution. Considering the global variation of propagation, each country has taken different positions, decisions and resources where the time for making different decisions has also been an important factor. In Mexico, the SARS CoV-2 situation has been confronted mainly with government decisions and the actions of the population. The successes or failures have impacted various dimensions of society in each of the states that make up the country. In this research, some impacted life dimensions are analyzed: Social, mental, educational, economic and environmental. It is possible to say that the impact of the pandemic were influenced, among other aspects; by the state of health and nutrition associated with the lifestyle in which the population was at the arrival of the pandemic. This impact is also influenced by commercial activities, which are linked to the economic mobility of those who buy and those who sell. Also, other aspects that have influenced the impact of this pandemic; it is possible to highlight the lack of culture on the part of the population in the use of face masks and the non-obligatory use of it by the leaders. This, added to various other factors, have had a great impact on the number of infected cases and deaths in the country; primarily in Mexico City and the State of Mexico. It is worth mentioning that, despite the negative impact due to the pandemic, there are also positive aspects. Finally, it is possible to say that it is necessary for the population to develop more awareness. The population has a definitive role in containing the pandemic and to incorporate the new changes, in its life in order to precisely preserve
\end{abstract}

Keywords: Social, mental, educational, economic, environmental, COVID-19.

\section{Introduction}

Mexico is in a critical phase (more than 100,000 deaths) of the pandemic due to the SARS-CoV-2 virus (UNAM, 2020; Conacyt, 2020) [1-2], after of the first reported cases of COVID in Mexico City (OMS, 2020a) [3]. The localities with the highest number of accumulated cases and deaths have been Mexico City and State of México [2]. The Mexican government implemented some health contingency strategies by COVID-19: suspension of financial activities, social distancing, cancellation of massive events, school closings, non-essential shops, and hand washing (Suarez et al., 2020) [4]. In the New Normality (NN) format (orderly, staggered and regionalized return to economic work activities) it was carried out based on 
Joel E. Valencia Hernández, Diana M. Sarmiento Páez, Raúl Romero Galindo, David A. Saucedo Alfonzo, Edgar O. López de León, Claudia Hernández Aguilar

Impact of COVID-19 in Mexico: A vision

an "Epidemiological Traffic Light" (Dimas, 2020) [5]. In addition, due to problem of metabolic syndrome in the population (ENSANUT, 2018) [6], one factor that complications the COVID-19 was applied the modification to the Official Mexican Standard NOM-051-SCFI/SSA1-2010 (food labeling) (DOF, 2020) [7]. Also, extraordinary program "today does not circulate" (Infobae, 2020) [8], etc. has been established.

The measures of "stay at home", social distancing, use of face mask, and COVID diagnostic tests, as well as follow-up of sick cases, etc. were not mandatory at the beginning of the pandemic. Of this way, the population depending on their educational, economic, cultural, geographical level, age, etc. complied or not the established recommendations. Later some states made it mandatory, at least the use of face masks. Causing, that the pandemic has not been able to contain and thus health sector workers have a strong physical and mental exhaustion and as well as a large number of deaths (Coria-Lorenzo, 2020; Villasís-Keever and García-Bolaños 2020; Martinez-Fierro et al., 2020) [9-11]. In addition, they did not have the most adequate working conditions in general to face the pandemic, including attacks that at some point have also suffered during the pandemic (Caldera-Villalobos et al., 2020) [12].

Mexico facing, a serious complex problem that has caused a series of impacts in different dimensions of social life, economic, educational, health, environmental, cultural, and political dimensions, among others [13-17]. In this context, some of the impacts that the COVID pandemic has brought in Mexico are detailed below. Impact in a country with more than 100 million inhabitants and divided into 32 locations (INEGI, 2020a; WLE, 2020) [18-19]. The amount of population by state, it is possible to observe in Figure 1a.

\section{Social Impact}

COVID-19 reached a Mexican population, characterized by a problem of previous chronic diseases such as hypertension, diabetes, obesity, diseases of the respiratory system and cardiovascular diseases, which has caused greater vulnerability and severity to infection [GOB.MX, 2020; Bello-Chavolla et al., 2020; Parra-Bracamonte et al., 2020; Hernadez-Galdamez, 2020] [20-23]. Due to the prevalence of metabolic syndrome, diabetes, obesity and hypertension (ENSANUT, 2018) [6], society is exposed to a greater risk of the COVID-19 disease. Figure $1 \mathrm{~b}$ and Figure 1c show a map of the percentage of the population with obesity and hypertension problems (ENSANUT, 2018) [6]. The states with the highest percentage of the population with obesity (ages 12-19 years) are Campeche, Colima, Quintana Roo, Sonora, Tabasco, Veracruz and Yucatán. In relation to hypertension, the states with the highest percentage of hypertensive population are Campeche, Chihuahua, Coahuila, Sonora, Tabasco, Veracruz, Yucatán. Being hypertension the disease that reaches the highest percentage of the population that suffers from it in the country. Of this way, the population faces a greater risk of mortality due to COVID-19, the mortality rate in Mexico has been at the moment 10\% (DGEM, 2020) [24]. In addition to the fact that not all the population has a health system within reach, such as indigenous populations (Diaz de Leon-Martinez et al., 2020) [25]. In Mexico there are percentages of the population between 15 - 29\% with extreme poverty in the south of the country (Figure 1d). The states of greatest poverty are Guerrero, Oaxaca and Chiapas (CONEVAL, 2019) [26]. Although it is true, they are the states with the greatest poverty, and the least reach to health systems. They are not the ones with the highest number of accumulated cases or deaths (Figure 1e and Figure 1f). In general, COVID-19 due to SARS-CoV-2 is the leading cause of death compared to the previous year (WHO, 2020) [27].

In Mexico, the current positive cases of COVID-19 are associated with comorbidities mainly of hypertension and obesity with $18.53 \%$ and $16.67 \%$ respectively. And in cases of deaths, $45.56 \%$ with hypertension and $38.57 \%$ with diabetes, followed by $23.69 \%$ with obesity. Which gives a relationship that 2 out of 10 deaths from COVID-19 suffered from obesity, 4 out of 10 had hypertension and 3 out of 10 had diabetes. This information should highlight the importance of the process of taking care of health and of eating a healthy and healthy diet. In times of COVID-19 and in the future, as preventive health stages. In this way, the Government of Mexico decided to incorporate nutrition subjects at the basic level (GOB.MEX, 2020) [28]. Since the need to re-educate the population is evident, likewise, the development of nutritious and low-carbohydrate basic products is important. 

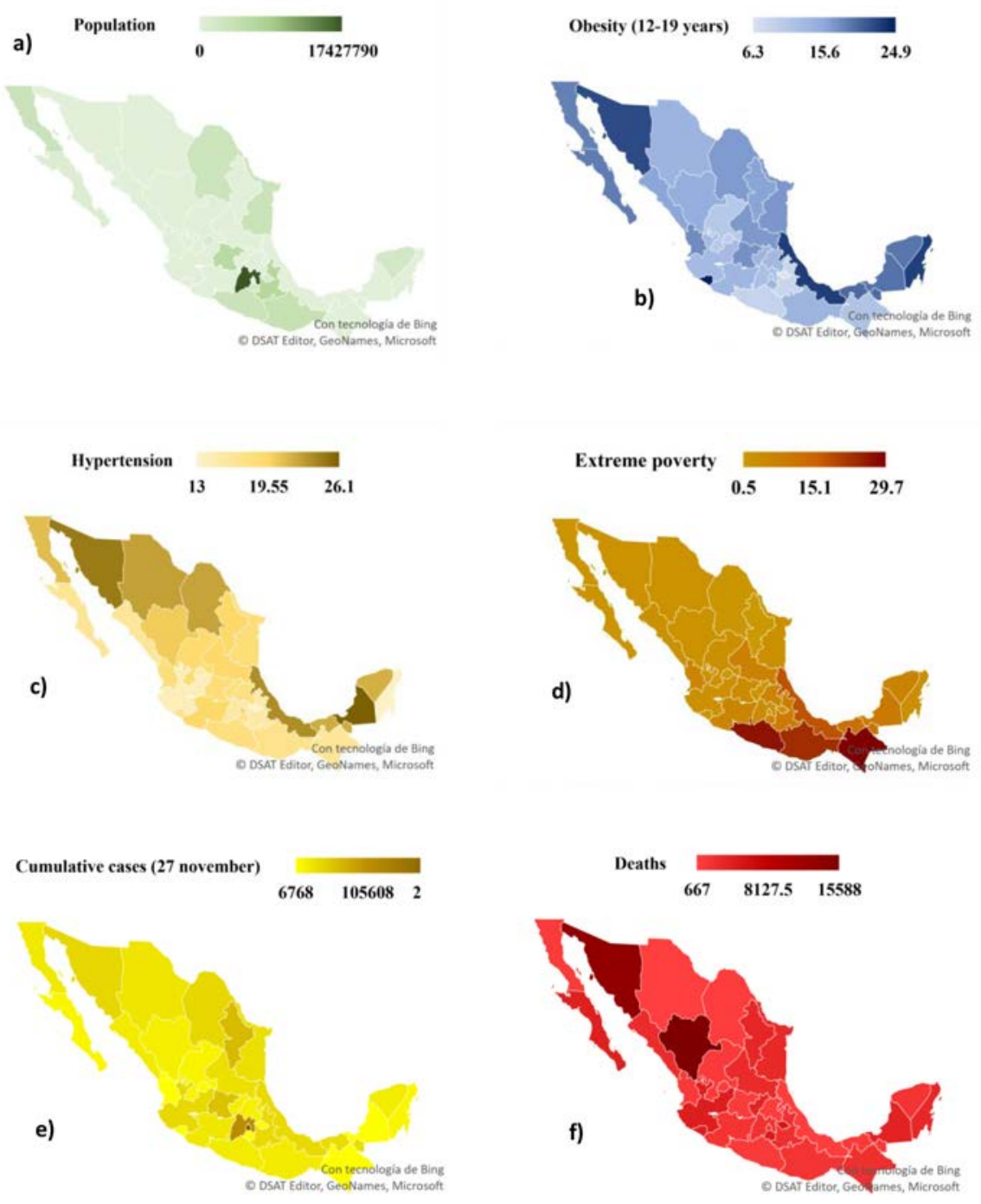

Figure 1: Indicator of Mexico a) Population (number of habitants), b) Obesity (\% population 12-19 years), c) Hypertension, d) Extreme poverty (\%), e) Cumulative cases, f) Deaths. According to UNAM, CONACYT, ENSANUT, etc. [1,6, 18, 19, 47, 48]. 
Joel E. Valencia Hernández, Diana M. Sarmiento Páez, Raúl Romero Galindo, David A. Saucedo Alfonzo, Edgar O. López de León, Claudia Hernández Aguilar

Impact of COVID-19 in Mexico: A vision

The COVID-19 pandemic has caused emotional disorders that led to eating disorders, one of them is the increase in cravings for junk food and / or sweets that is directly related to weight gain. According to the UVM Public Opinion Center (2020) [29], 30\% of those surveyed indicate that they eat much more than before the pandemic where are $24 \%$ women, and $16 \%$ men. This is reflected in people's weight gain, as $47 \%$ of people reported that they gained weight. However, other sectors of the population have been concerned with maintaining or creating healthier habits, where $35 \%$ of those surveyed indicate that their healthy habits are the same as before, and $32 \%$ that they are healthier than before and the $17 \%$ of the population underweight.

Food security (access to food) in households was also affected by the pandemic. It has been identified that only $35.9 \%$ of the CDMX households had food security, but the most affected population is households with minors where they only obtained $26 \%$ of food security, where severe food insecurity affects $18.8 \%$ and the moderate to $22.4 \%$ of households with a lower socio-economic level. In contrast, these indicators are only $2.2 \%$ and $6.1 \%$, respectively, among households with a higher socioeconomic level (UNICEF, EQUIDE and EVALÚA CDMX, 2020) [30]. However, the purchase decision is also important about the foods that poor families can buy, where it is based on more carbohydrates than protein.

For the care of the population, in the case of Mexico City, the government enabled the COVID-19 detection and diagnosis service. According to survey ENCOVID-CDMX (2020) [30] the 7.3\% of the households surveyed there was at least one person with symptoms associated with COVID-19, where only about half of these cases were contacted by detection and diagnosis services authorized by the Government of Mexico City (Locatel, SMS and others).

\section{Mental Impact}

The majority of society lives in a context of uncertainty due to the current situation, affecting their human behavior individually and collectively. This uncertainty, produced by the pandemic itself, is also increased by government decisions, the media (negative news value), false information from social networks, social norms, social and cultural inequality, political preferences, access to scientific information, etc. (Van Bavel et al., 2020) [31]. The response of the population to this is manifested in emotional responses (fear, anxiety and anguish), changes in behavior, beliefs and knowledge, individualistic behaviors, social and individual psychological aspects (González Martín, N. and áceres Nieto, E., 2020) [32] or defensive responses: skepticism, optimism and indifference bias, "reckless behavior" derived from denial or rejection of the situation, among others (Acuna-Zegarra, M. et al., 2020) [33]. Other problems related to mental health are disorders derived from the fear of contracting COVID-19.

The Covid-19 pandemic caused an unprecedented mental health crisis throughout the American Continent, with half of adults stressed (Del Valle, and Juárez, 2018; EL UNIVERSAL, 2020) [34-35]. In Mexico, according to Villavicencio-Ayub (2020) [36] before the pandemic, $25 \%$ of the workers presented some mental disorder such as depression, although not all required psychiatric treatment. Due to the pandemic and work at home, among other causes, it is estimated that stress affects $43 \%$ of the working population in Mexico.

Contreras-Ibañez (2020) [37] indicated that the general average of the global stress index of a mexican sample is 2.71 , observing that it has a moderate degree of stress compared to the rest of the world. It was found a negative correlation between stress and age. Young people around 20 years of age presented greater stress than adults over 65 years old. It also indicated that women presented more physical or emotional tension than men. Other factors include the multiple tasks they must do, as well as childcare during the pandemic. It is considered that 6 out of 10 mothers were in charge of guiding their children in their classes and schoolwork [37]. The stress also occurred due to falling ill with COVID-19

The population of Mexico City (the population most affected by the pandemic), according to statistical data indicated different levels of concern about COVID; $65.8 \%$ high, $24.6 \%$ medium and $9.6 \%$ low concern. Regarding to use of face masks, $83.4 \%$ of Mexicans and $89.1 \%$ of the surveyed capitalists make correct use of the mask (Centro de Opinión pública UVM, 2020) [29] only in some places. There are delegations 
and communities where they do not finish adjusting to the use of face masks to be co-responsible for their health and that of others. In fact, as a result of "good end" there was a drastic increase in cases of infected. However, there are still people who do not use the masks, much less stay at home. Being an alarming situation, for Mexico City and the State of Mexico.

Another emotional impact that the population affected by COVID-19 in Mexico has experienced is coping with and recovering from grief in times of pandemic. The critical situation of not being able to perform rituals for the family that dies from COVID-19 or other causes. Nor has accompanying the disease perhaps caused a longer time of mourning (Arlanzón E., 2020) [38]. This can also generate feelings of anger and resentment in some people and / or family members who have lost a loved one to COVID-19 causes. On the other hand, there are people who, due to this pandemic, have learned to value more life and time shared with their families, for which they are grateful and enjoy the treasures that God gives us, which is life, health, love of family and friends, and have allowed themselves to increase and grow spiritually and draw closer to the presence of God, filling them with peace and faith to cope with the times of COVID-19.

Reflection, rediscovery of the common good, human solidarity, philosophy of life (Velázquez, 2020), [39], adaptation, optimization of resources, reeducation and hygiene habits (Nielsen, 2020) [40], were positive aspects developed by some fraction of the population in the face of this pandemic. In social security, there has been a reduction in crimes such as kidnappings, extortion and theft and robbery of vehicles (ONC, 2020; Arciniegas, 2020; Balmori de la Miyar, et al., 2020) [41-43]. All these aspects modify the life of the country's society in the different states. The economic, educational and social differences in the face of this pandemic are highlighted.

\section{Educational Impact}

Mexico has suspended face-to-face classes at the national level in order to reduce the chains of contagion, this fact is supported by the experience of previous pandemics, which would help reduce it by $15 \%$ (OECD, 2020) [44]. For this reason, the government, in addition to translating educational materials into different dialects to make them reach indigenous communities, has implemented strategic models for distance education (Mérida and Acuña, 2020) [45] through television programs, telephone service, radio and platforms. Therefore, the Mexican government seeks to meet the demand of approximately 36 million students (OECD, 2020) [44].

The health emergency has highlighted the educational inequality that exists in Mexico (Lloyd, 2020) [46], generating ethical questions regarding the equity of the implemented model since in Mexico $48.8 \%$ of the population is in a state of poverty (CONEVAL, 2019) [47].

On the other hand, in Mexico there are 72 indigenous languages (INEGI, 2015) [48] of which, about a million people do not speak Spanish (INEE, 2018) [49]. In addition, the high cost of mobile devices such as computers and cell phones complicate the education situation, also students are forced to hire an internet service [50]. Likewise, it is estimated that $56.4 \%$ of the population has internet, and $43 \%$ of the population uses a computer. However, only $76.6 \%$ of the urban population and $47.7 \%$ of the rural population have access to the internet (IFT, 2020) [51]. It is clear that access to Information and Communication Technologies (ICT), is not equitable and affects students of any educational level; due to the social class condition that determines who can access and learn from online education (INEGI, 2018) [52]. There is a digital divide as a consequence of economic inequality (Winters, N, et al., 2020) [53].

Other interesting aspects that occurred in the educational dimension is that there was an increase in the time dedicated to carrying out educational tasks. Also, there was greater communication with teachers and companionship, increased family coexistence, etc. (MEJOREDU, 2020) [54], depending on the school level.

\section{Economic Impact}

Another important impact derived from the pandemic in Mexico is seriously in the economic dimension. On March 30, the "agreement declaring a health emergency due to illness caused by the SARS-CoV2 
Joel E. Valencia Hernández, Diana M. Sarmiento Páez, Raúl Romero Galindo, David A. Saucedo Alfonzo, Edgar O. López de León, Claudia Hernández Aguilar

Impact of COVID-19 in Mexico: A vision

virus (COVID-19)" was published, through which essential and non-essential activities in the economy are defined. In this way non-essential activities had to be stopped during the quarantine. But this provision was not strict as in other parts of the world (OIT, 2020) [55]. However, anyway, there was a decline in the national economy. As in the world, in Mexico the industrial sector is affected, such as manufacturing, accommodation, restaurants, and the street trade, etc. As well as various events that finally had to be canceled were affected (Shrestha et al., 2020) [56].

Many of the activities were temporarily closed, the workforce was unable to find work, which impacted 12 million economically active people. The pandemic also affected informal employment, having a contraction of 8 percentage points that is, it fell from $55.7 \%$ to $47.7 \%$, however, this later had some small recovery, but currently due to a drastic increase in cases, again economic activities is in danger; there are festivities and events that are canceled (OIT, 2020) [55].

The commercial opening is one of the most complicated decisions in the country since it has to do with the possible mobility of the population. Having consequences, such as the increase in cases infected by COVID-19. In recent times, this has happened after the commercial activity intensified by the period of "Buen Fin" (November, 9-20) and by purchases at the end of the year. Although it is true, sales intensified, but also, the mobility of the population.

The indicator of Gross Domestic Product (GDP) decreased 17.1\% in real terms during the second quarter of 2020 compared to the immediately previous quarter (INEGI, 2020b) [57]. In addition, the loss of 1,117,584 formal jobs from March to July 2020, most of which were permanent jobs (IMSS, 2020) [58]. In August, 92,390 formal jobs were recovered. However, this has implied that more formal jobs have been destroyed in five months than those created in 2019, this means that the reactivation and recovery of formal jobs will not be rapid (OIT, 2020) [55]. Likewise, the closure of 1 million 10 thousand 857 establishments (20.81\%) closed their doors permanently, being the small and medium with the highest percentage of permanent closings $(21.17 \%)$ compared to the micro establishments that had 20.80 percent closings.

Regarding the population and depending on their economy, some of them were able to acquire purchasing habits using online shopping applications, grocery delivery and restaurants (Survey, 2020) [59]. Worth mentioning that much of the population. They do not even imagine what to buy because they have gone through unemployment crisis inside their homes and they barely have to eat. Of this way, in Mexico, social programs with economic support were implemented, in CDMX $45.8 \%$ of the people interviewed in the ENCOVID_CDMX [30] reported that at least one person in their household received some support, and priority was given to households with fewer resources and/or with child population.

\section{Environmental Impact}

During the pandemic, vehicular activity decreased and many people stayed at home and as a consequence the concentration of emissions decreased in several states; especially in the metropolitan area, where there was an improvement in air quality in Mexico City during the first weeks after the quarantine, finding reductions in concentrations of $\mathrm{NO}^{2}, \mathrm{SO}^{2}$, and $\mathrm{PM} 2.5$ (although later the situation tends to reverse) (ECLAC, 2020) [60]. In Mexico City, there was a 2\% reduction in pollutants compared to the week before the quarantine (Rodríguez-Urrego and Rodríguez-Urrego, 2020) [61]. In particular, ozone indicators decreased during the blockade period compared to the pre-blockade period and compared with the historical average of the same interval of the last 5 years. (Kutralam-Muniasamy, et al., 2020) [62]. Although the satellite images show the same concentration of ozone with that of the previous year, it is found that ozone precursors did decrease (during March-May 2020) (Peralta, et al., 2020) [ 63].

Others environmental aspects were also impacted, there was a reduction in the use of plastics during the confinement (Mora, 2020) [64] and on some beaches in Mexico they look cleaner and clearer (ZambranoMonserrate et al., 2020) [65]. On the other hand, in relation to the increase in garbage generated by the use of protective elements, such as face masks, which has produced another subsequent contamination.

According to the above described, in a synthesized way, Figure 2 presents a rich vision of the impacts on the different dimensions of life in Mexico. It is presented according to the perception of fellow students and 


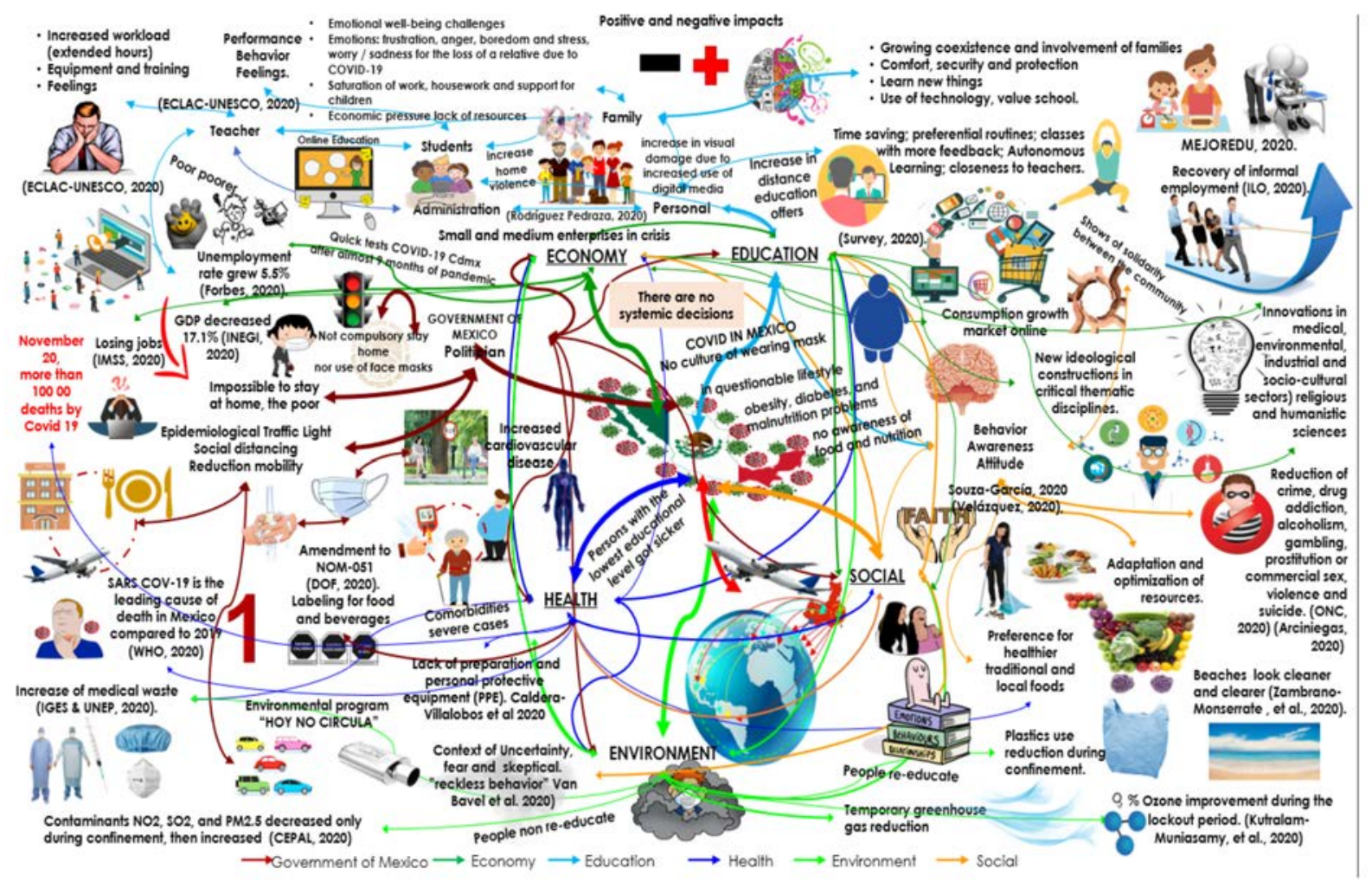

Figure 2: Impacts of Sars-Cov 2 in Mexico. according to UNAM, CONACYT, ENSANUT, etc. [1,6, 18, $19,47,48]$.

evidence reported in the literature. It can be seen that there are positive and negative impacts. Because although it is true it has been a tragedy, there are also positive aspects in this situation that are worth rescuing and it is possible to observe in Figure. As mentioned, there are positive aspects related to the environment, the opportunity to spend more time with the family, etc.

Finally, it is interesting to observe the behavior of some indicators of the country, such as Cumulative cases (November 27), Deaths, Population, Homes with internet, Occupation in commerce, Diabetes $>20$, Hypertensive $>20$, Obesity (12-19), Poverty (\%) (2018), Education, Tobacco consumption (10-19), Alcohol consumption $(>20)$, etc.

Through a principal components analysis, the relationships between the vectors representing each of the mentioned variables are observed (Figure 3). In this representation, the vectors with the smallest angle formed between them are the ones that are most correlated. Then, it is observed how the vector that represents the variable of accumulated cases of infected by COVID-19 and number of deaths by state, correlate more with the amount of population with occupation in trade that has to do with the mobility of people and by the other hand, with the educational level and the size of the state's population. In this way, one could think about the importance of stopping economic activity to reduce the cases that are currently occurring in Mexico, mainly in Mexico City, since the most correlated cases are infected by covid-19 and deaths is this indicator. According to those that are being considered in this research work. Another important factor is the educational level of the people, which could be related to their discipline to adjust to the regulations of the new normal, their type of employment, perhaps they had the opportunity to work from home and then they are less likely to be infected and possibly die. Of course, not counting that people in the health sector are the most damaged and the one with the highest number of deaths. 
Joel E. Valencia Hernández, Diana M. Sarmiento Páez, Raúl Romero Galindo, David A. Saucedo Alfonzo, Edgar O. López de León, Claudia Hernández Aguilar

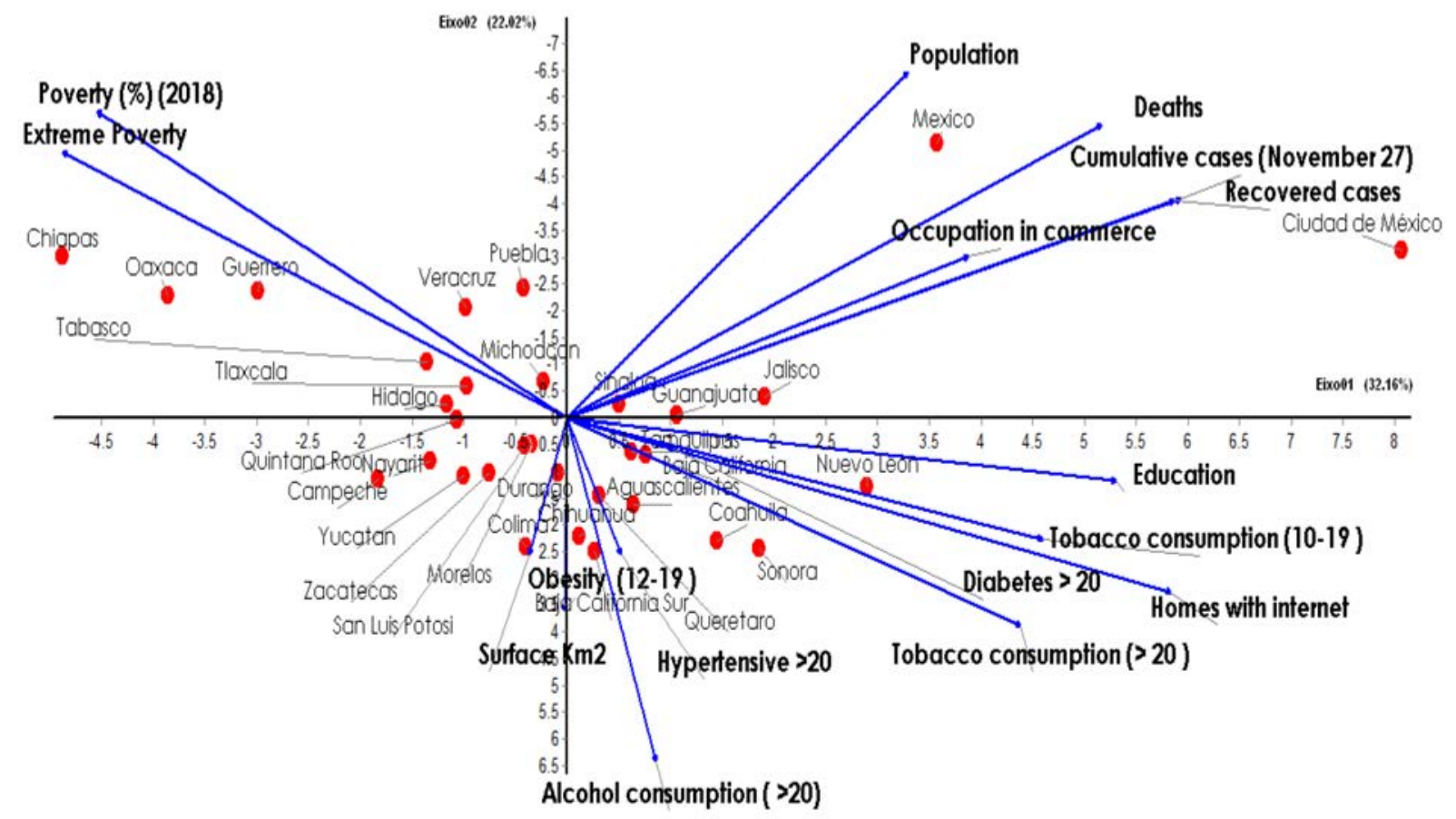

Figure 3: Impacts of Sars-Cov 2 in Mexico.) according to UNAM, CONACYT, ENSANUT, etc. [1,6, 18, $19,47,48]$.

\section{Conclusion}

The facts alert society to adapt to a new world, new habits, customs, thoughts.

There is the importance of looking inward and outward. This means being co-responsible for the other and the other (neighbor) and environment and also being responsible for oneself. So, constantly reprogram yourself, learn to develop more resilience, grow spiritually and also nutritionally stronger.

An unprecedented fact that teaches and transforms.-A fact that impacted life, and changed all its dimensions. Where a perspective from 50 years ago: transdisciplinarity.

Today it could support the formation of current and future students, where self-knowledge is greatly rescued, which will be a current and future support for all students. Know yourself.

"When I was a young man, I wanted to change the world.

I found it was difficult to change the world, so I tried to change my nation.

When I found I couldn't change the nation, I began to focus on my town. I couldn't change the town and as an older man, I tried to change my family.

Now, as an old man, I realize the only thing I can change is myself, and suddenly I realize that if long ago I had changed myself, I could have made an impact on my family. My family and I could have made an impact on our town. Their impact could have changed the nation and I could indeed have changed the world."

Unknown monk, c. 12th century [66]

We believe that there is still time to stop the most serious impacts of this pandemic. Hernandez and Dominguez (2020) [67] mention, act as if you and me, and all had COVID-19, because many of us could be atypical and then infect. In this way, in countries where insufficient tests are carried out, such as Mexico (which has recently been promoted in Mexico City), it could help to contain the pandemic. The population of Mexico City should be aware and there should be leaders who guide the best path and attitudes of all to achieve survival. 


\section{Acknowledgments}

The students of doctorate Joel, Diana, Raul, David and Edgar are grateful for support from Conacyt to the development of their studies. Dra. Hernández-Aguilar thanks students participating in this collaborative project, for their commitment and dedication. Likewise, she thanks to Masters, Doctors and postdoctoral students who have graduated from the research group ( biophysical systems applied to agriculture, food and medicine) for 13 years of walking through this perspective TD to investigate within the Graduate Program in Systems Engineering. In a special way, we thank everyone with whom we agree and participate in the process of teaching and learning. With the motto: WE ARE ALL TEACHERS, WE ARE ALL STUDENTS.

Author Contributions: : Research team members equally contributed.

Funding: No funding received for this research.

Conflicts of Interest: The authors declare no conflict of interest.

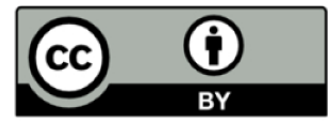

Copyright (C) 2021 by the authors. This is an open access article distributed under the Creative Commons Attribution License (https://creativecommons.org/licenses/by/4.0/), which permits unrestricted use, distribution, and reproduction in any medium, provided the original work is properly cited.

\section{References}

[1] UNAM (2020). Coronavirus en tiempo real, Liga: https://www.biomedicas.unam.mx/coronavirus/tiempo-real/ (consultada 10 de diceimbre, 2020)

[2] CONACYT (2020). Covid-19-México. Información General. https://datos.covid-19.conacyt.mx (consulta

[3] World Health Organization. (2020). Coronavirus disease 2019 (COVID-19): Situation report, 40.

[4] Suarez, V., Suarez Quezada, M., Oros Ruiz, S. \& Ronquillo de Jesus, E., (2020). Epidemiología de COVID-19 en México: del 27 de febrero al 30 de abril de 2020. Revista Clínica, 220(8), pp. 463-471.

[5] Dimas Huacuz, B., (2020). ABC de la COVID-19 Prevención, Vigilancia y Atención de la Salud en las Comunidades Indígenas y Afromexicanas, México: Instituto Nacional de los Pueblos Indígenas (INPI.

[6] ENSANUT, (2018). Encuesta Nacional de Salud y Nutrición 2018. https://ensanut.insp.mx/encuestas/ ensanut2018/doctos/informes/ensanut_2018_presentacion_resultados.pdf, Consulta, December, 1.

[7] DOF, (2020). NOM-051NOM-051-SCFI/SSA1-2010, México: Diario Oficial.

[8] Infobae, (2020). Hoy No Circula extraordinario por Fase 3 del coronavirus: todo lo que debes de saber. [En línea] Available at: https://www.infobae.com/america/mexico/2020/04/22/hoy-no-circula-extraordinario-porfase-3-del-coronavirus-todo-lo-que-debes-de-saber/ [Último acceso: 111 2020].

[9] de Jesús Coria-Lorenzo, J. (2020). Covid-19 y su relación con la morbilidad, mortalidad, economía y "quédate en casa". Acta Pediátrica de México, 41(3).

[10] Villasís-Keever, M. Á., \& García-Bolaños, C. (2020). COVID-19: It marks a before and after in Mexico, final point or period?. Revista Mexicana de Pediatría, 87(2), 43-45.

[11] Martinez-Fierro, M. L. y otros, (2020). The role of close contacts of COVID-19 patients in the SARS-CoV-2 transmission: an emphasis on the percentage of nonevaluated positivity in Mexico. American Journal of Infection Control, pp. 1-6.

[12] Caldera-Villalobos, C. y otros, (2020). The Coronavirus Disease (COVID-19) Challenge in Mexico: A Critical and Forced Reflection as Individuals and Society. Public Health, 8(337), pp. 1-4.

[13] Malo Álvarez, S., Maldonado-Maldonado, A., Gacel-Ávila, J., \& Marmolejo, F. (2020). Impacto del COVID-19 en la educación superior en México. Revista de Educación Superior en Améica Latina, (8). 
Joel E. Valencia Hernández, Diana M. Sarmiento Páez, Raúl Romero Galindo, David A. Saucedo Alfonzo, Edgar O. López de León, Claudia Hernández Aguilar

Impact of COVID-19 in Mexico: A vision

[14] Muñoz Martínez R., \& Cortez, R. (2020). Impacto social y epidemiológico del Covid-19 en los Pueblos Indígenas de México. Debates Indígenas.

[15] Cota, J. E. M. (2020). COVID-19 y el empleo en México: impacto inicial y pronósticos de corto plazo. Contaduría y administración, 65(4), 8.

[16] López, J. T. M., Martínez, L. R., \& Coria, A. E. I. (2020). Grado de escolaridad en México y su impacto sobre la mortalidad por Covid-19: una breve reflexión. Archivos en Medicina Familiar, 23(2), 63-65.

[17] Nodar, J. M. F. (2020). Covid-19 y su impacto en el turismo en Oaxaca (México). Desarrollo, economía y sociedad, 9(1), 29-35.

[18] INEGI 2020a. Comunicado de prensa núm. 302/20 9 de julio de 2020 estadísticas a propósito del día mundial de la población (11 de julio) datos nacionales.

[19] WLE, (2020). https://www.worldlifeexpectancy.com/country-health-profile/mexico.

[20] GOB.MX , (2020). Criterios para las poblaciones en situación de vulnerabilidad que pueden desarrollar una complicación o moéxico: s.n.

[21] Bello-Chavolla, O. Y., Bahena-Lopez, J. P., Antonio-Villa, N. E., Vargas-Vázquez, A., González-Díaz, A., Márquez-Salinas, A., ... and Aguilar-Salinas, C. A. (2020). . Predicting Mortality Due to SARS-CoV-2: A Mechanistic Score Relating Obesity and Diabetes to COVID-19 Outcomes in Mexico. J Clin Endocrinol Metab, 105(8).

[22] Parra-Bracamonte, G. M., Lopez-Villalobos, N. \& Parra-Bracamonte, F. E., 2020. Clinical characteristics and risk factors for mortality of patients with COVID-19 in a large data set from Mexico.

[23] Hernández-Galdamez, D. R., González-Block, M. Á., Romo-Dueñas, D. K., Lima-Morales, R., HernándezVicente, I. A., Lumbreras-Guzmán, M., \& Méndez-Hernáández, P. (2020). . Increased Risk of Hospitalization and Death in Patients with COVID-19 and Pre-existing Noncommunicable Diseases and Modifiable Risk Factors in Mexico. Archives of Medical Research, 51(7), pp. 683-689.

[24] DGEM, Dirección General de Epidemiologia de México (2020). Información General COVID19 México. Nacional. Consulta: 14 Diciembre de https://datos.covid-19.conacyt.mx/\#DOView.

[25] Diaz de Leon-Martinez, L. y otros, (2020). Critical review of social, environmental and health risk factors in the Mexican indigenous population and their capacity to respond to the COVID-19. Science of The Total Environment, Volumen 733, pp. 1-6.

[26] CONEVAL, (2019). 10 años de medición de pobreza en México, avances y retos en política social, Ciudad de México: Dirección de información y comunicación social. https://www.coneval.org.mx/Paginas/principal.aspx.

[27] WHO, (2020). www.worldlifeexpectancy.com. [En línea] Available at: https://www.worldlifeexpectancy.com/ country-health-profile/mexico [Último acceso: 111 2020].

[28] Gobierno de la ciudad de México (2020). Medidas implementadas en la Ciudad de México durante fase 3 por emergencia sanitaria de COVID-19. Publicado el 23 Abril 2020 Recuperado el 5 Noviembre de 2020 de https://covid19.cdmx.gob.mx/comunicacion/nota/medidas-implementadas-en-la-ciudad-de-mexico-durantefase-3-por-emergencia-sanitaria-de-covid-19.

[29] Centro de Opinión pública UVM (2020). Alimentación, actividad física y ocio durante el confinamiento. Recuperado el 8 Noviembre de 2020 de Alimentación, actividad física y ocio durante el confinamiento_0.pdf (uvm.mx)

[30] UNICEF, EQUIDE y EVALÚA CDMX (2020). Encuesta de seguimiento de los efectos del COVID-19 en el bienestar de los hogares en la ciudad de México - ENCOVID-CDMX. Resumen de resultados Julio 2020 Recuperado el 5 noviembre de 2020 de https://www.unicef.org/mexico/media/4781/file/ENCOVID-CDMX.pdf.

[31] Van Bavel, J. J., Baicker, K. \& Willer, R., (2020). Using social and behavioural science to support COVID-19 pandemic response. Nature Human Behaviour, Volumen 4, pp. 460-471.

[32] González Martín, N. \& Cáceres Nieto, E., (2020). Emergencia sanitaria por Covid-19: constructivismo jurídico, gobierno, economía y cambio conductual., Ciudad Universitaria, Coyoacán, 04510 Ciudad de México: ISBN Serie Opiniones Técnicas sobre Temas de Relevancia Nacional: 978-607-30-1256-0.

[33] Acuna-Zegarra, M. A. y otros, (2020). The SARS-CoV-2 epidemic outbreak: a review of plausible scenarios of containment and mitigation for Mexico. medRxiv, pp. 1-33. 
[34] Del Valle, C., \& Juárez, D. B. (2018). Estudio Diagnóstico del Derecho a la Alimentación Nutritiva y de Calidad. Primera edición: octubre de 2018 Consejo Nacional de Evaluación de la Política de Desarrollo Social Av. Insurgentes Sur 810.

[35] ELUNIVERSAL (2020). La mitad de adultos en México sufren estrés por la pandemia del Covid-19: OPS. Publicado el 18 agosto de 2020. Recuperado el 5 de Noviembre de 2020 de La mitad de adultos en Méico sufren estrés por pandemia del Covid-19: OPS (eluniversal.com.mx).

[36] Villavicencio-Ayub E., (2020). En México, la mitad de los trabajadores tendría afectación mental por estrés. 30 de Septiembre de 2020. Recuperado el 6 Noviembre de En México, la mitad de los trabajadores tendría afectación mental por estrés - Infobae.

[37] Contreras-Ibañez, (2020). Mexicanos, cerca de los más altos niveles de estrés: UAM. Mayo 25 de 2020. Recuperado el 6 Noviembre de 2020 de Mexicanos, cerca de los más altos niveles de estrés: UAM • Forbes México.

[38] Arlanzón E, Cabrera CE, García N, Pireto P, Rey P, Robles M, et al. (2020). Guía para trabajar el duelo con personas que sufren una perdida en tiempos de coronavirus. Recuperado el 30 de Noviembre de http://www.educa.jcyl.es/educacyl/cm/crol/pdfCrol?idMmedia=1394995.

[39] Velázquez, L., (2020). The role of philosophy in the pandemic era. BIOETHICS UPdate, 6(2), pp. 92-100.

[40] Nielsen, (2020). Coronavirus (covid-19) y su evolución en el consumo en méxico. [En línea] Available at: https://www.nielsen.com/mx/es/insights/article/2020/coronavirus-covid-19-y-su-evolucion-en-el-consumoen-mexico/ [Último acceso: 0111 2020].

[41] ONC, (2020). La prevencion del delito en tiempos del COVID-19, México: Observatorio Nacional Ciudadano Seguridad, Justicia y Legalidad.

[42] Arciniegas, Y., (2020). Durante la pandemia, el crimen disminuye en Ciudad de México y aumenta en el país. [En línea] Available at: https://www.france24.com/es/20200602-ciudad-de-mexico-disminuye-violencia-covid19aumenta-en-mexico [Último acceso: 111 2020].

[43] Balmori de la Miyar, J. R., Hoehn-Velasco, L. \& Silverio-Murillo, A., (2020). Druglords don't stay at home: COVID-19 pandemic and crime patterns in Mexico City. Journal of Criminal Justice, pp. 1-13.

[44] OCDE (2020). El impacto del COVID-19 en la educación - Información del Panorama de la Educación, s.l.: Education at a glance.

[45] Mérida, Y. and Acuña, L. A. (2020). Covid-19, Pobreza y Educación en Chiapas: Análisis a los Programas Educativos Emergentes. Revista Internacional de Educacion para la Justicia Social, 9(3), pp. 61-82.

[46] Loyd, M. (2020). Desigualdades educativas y la brecha digital en tiempos de Covid-19. SinObraDerivada 4.0 Internacional (CC BY-NC-ND 4.0), pp. 115-121.

[47] CONEVAL (2019). 10 años de medición de pobreza en México, avances y retos en política social, Ciudad de México: Dirección de información y comunicación social. https://www.coneval.org.mx/Paginas/principal.aspx.

[48] INEGI (2015). Lenguas indígenas en México y hablantes (de 3 años y más) al 2015. [En línea] Disponible en: INEGI.org.mx [Último acceso: 27 noviembre 2020].

[49] INEE (2018). ¿Cuánta población indígena hay en México?. [En línea]Disponible en: www.INEE.edu.mx [Último acceso: 27 noviembre 2020].

[50] Ramli, M. F., Majid, M. and Badyalina, B., (2020). Impeding Factors Towards the Effectiveness of Online Learning During Covid-19 Pandemic among Social Sciences Students. International Journal of Learning and Development, 10(4), p. 37.

[51] IFT (2020). En méxico hay 80.6 millones de usuarios de internert y 86.5 millones de usuarios telefónicos celulares, Ciudad de México: s.n.

[52] INEGI (2018). ¿Cuánta población indígena hay en México?. [En línea] Disponible en: www.INEE.edu.mx. [Último acceso: 27 noviembre 2020].

[53] Winters, N., Eynon, R., Geniets, A., Robson, J., \& Kahn, K. (2020). Can we avoid digital structural violence in future learning systems?. Learning, Media and Technology, pp. 1-19. 
Joel E. Valencia Hernández, Diana M. Sarmiento Páez, Raúl Romero Galindo, David A. Saucedo Alfonzo, Edgar O. López de León, Claudia Hernández Aguilar

Impact of COVID-19 in Mexico: A vision

[54] MEJOREDU, (2020). Experiencias de las comunidades educativas durante la contingencia sanitaria por covid-19 Educación básica. Informe ejecutivo, México, Ciudad de México: Comisión Nacional para la Mejora Continua de la Educación.

[55] Organización Internacional del Trabajo (2020). 'México y la crisis de la COVID-19 en el mundo del trabajo: respuestas y desafíos'. Liga : https://www.ilo.org/mexico/noticias/WCMS_757501/lang-es/index.htm (consultado 6 de diciembre 2020)

[56] Nistha Shrestha, Muhammad Yousaf Shad, Osman Ulvi, Modasser Hossain Khan, Ajlina Karamehic-Muratovic, Uyen-Sa, D.T. Nguyen, Mahdi Baghbanzadeh, Robert Wardrup, Nasrin, Aghamohammadi, Diana Cervantes, Kh. Md Nahiduzzaman, Rafdzah Ahmed Zaki, Ubydul Haque, (2020). The impact of COVID-19 on globalization.

[57] INEGI, (2020b). Producto interno bruto de méxico durante el segundo trimestre de 2020, s.l.: comunicado de prensa núm. 407/20.

[58] IMSS, (2020). Puestos de trabajo Gobierno de México. [En línea] Available at: https://public.tableau.com/profile/imss.cpe\#!/vizhome/Histrico_4/Empleo_h?publish=yes [Último acceso: 1 Noviembre 2020].

[59] Survey, (2020). Mexican consumer sentiment during the coronavirus crisis. [En línea] Available at: https://www.mckinsey.com/business-functions/marketing-and-sales/our-insights/survey-mexicanconsumer-sentiment-during-the-coronavirus-crisis [Último acceso: 1011 2020].

[60] ECLAC-UNESCO, (2020). Education in the time of COVID-19, Santiago Office Regional Bureau for Education in Latin America and the Caribbean: United Nations, 2020.

[61] Rodríguez-Urrego, D. \& Rodríguez-Urrego, L., 2020. Air quality during the COVID-19: PM2.5 analysis in the 50

[62] Kutralam-Muniasamy, G. y otros, (2020). Impacts of the COVID-19 lockdown on air quality and its association with human mortality trends in megapolis Mexico City. Air Qual Atmos Health., pp. 1-10.

[63] Peralta, O. y otros, (2020). Ozone over Mexico City during the COVID-19 pandemic. Science of The Total Environment, pp. 1-12.

[64] Mora, K., (2020). Toneladas de residuos se recuperan con la reactivación. razon.com.mx L.R.H.G. INFORMATIVO, S.A. DE C.V.. [En línea] Available at: https://www.razon.com.mx/ciudad/baja-basura-plasticos-17pandemia-408524 [Último acceso: 111 2020].

[65] Zambrano-Monserrate, M. A., Ruano, M. A. \& Sanchez-Alcalde, L., (2020). Indirect effects of COVID-19 on the environment. Science of the Total Environment, 728(138813), pp. 1-4.

[66] https://harrisrichard.com/tag/i-wanted-to-change-the-world-poem/

[67] Hernández-Aguilar, C., \& Pacheco, F. D. (2020). Relationship of airports, population, competitiveness indexes and human development with confirmed and deceased cases by COVID-19: Need for transdisciplinary systemic decisions. Transdisciplinary Journal of Engineering \& Science, Vol. 11, pp. 91-102.

\section{About the Authors}

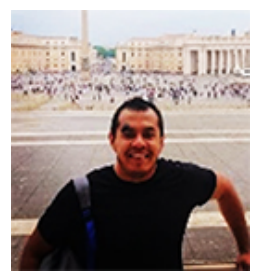

Joel Eduardo Valencia Hernández is a seventh (last) semester student of the Doctoral Program in Systems Engineering of the National Polytechnic Institute. Member of the Transdiciplinary research group on Sustainable Biophysical Systems led by Dr. Claudia Hernández Aguilar and Dr. Flavio Arturo Domínguez Pacheco. Master in Systems Engineering where he developed a test bench for vegetable lubricants. Currently, he is writing his doctoral thesis on the use of non-toxic nanoparticles as additives in vegetable and mineral based lubricants in mechanical applications that reduce the negative impact on the environment. As a researcher, he considers it necessary to 
disseminate knowledge through the collaboration of researchers from different scientific disciplines, together with the public and private sectors, as well as with citizens, to address complex social challenges.

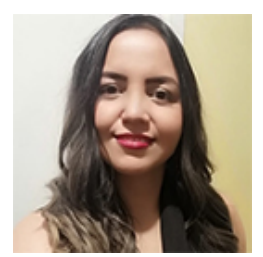

Diana Marcela Sarmiento Páez is a sixth semester student of the Doctorate program in Systems Engineering within the Engineering Systems research line at the National Polytechnic Institute (IPN) of Mexico. She is an Industrial Engineer graduated from the Industrial University of Santander (UIS) in Colombia. She is Master in Systems Engineering where investigated the sanitary quality of staple food: bread. She is currently looking for methods to improve sanitary quality. As a young future researcher, she is enthusiastic about contributing to useful topics for others

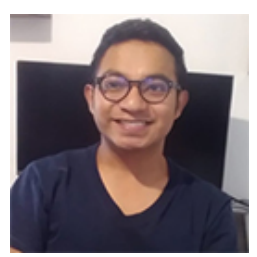

Raúl Romero Galindo is a second semester student of the Doctorate in Systems Engineering at the National Polytechnic Institute. Technologist by training, Master of Science in Biosystems Engineering, and specialist in Greenhouse Engineering. He has worked as a teacher at the intermediate and higher level in subjects related to mechatronics. In 2016, he obtained 1st place in the regional scientific audiovisual competition with the work entitled "Motus I." consequently, he co-founded Collective Motus. He is currently a member of the Biophysical Systems Research group from a transdisciplinary perspective -ESIME-SEPI. He has also collaborated in various Art, Science and Technology projects with various artists and science disseminators in the state of Querétaro. In addition, he has participated in different projects related to agriculture, permaculture, and school gardens. Raúl believes in the transgression of disciplinary limits as a process of humanization with science and society; to seek solutions to tangible problems through systems thinking, scientific rigor and a vision of the problem as a whole. In congruence with the training received. Likewise, he is convinced of the need to interconnect with science and society through art as a process of communication of knowledge. He is passionate about research and likes to share with people every word, every result and every new knowledge that has been acquired

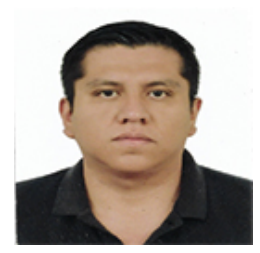

David Abraham Saucedo Alfonzo is a third semester student of the doctoral program in Systems Engineering, line of research engineering systems. With a specialty and Master's degree in Systems Engineering at ESIMEZacatenco of the National Polytechnic Institute (Mexico). Main interests in the area of health and quality of life.

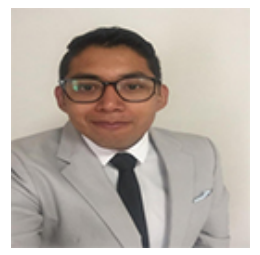

Edgar Omar López de Leóón is a student in the seventh semester of the PhD program in systems engineering at 
Joel E. Valencia Hernández, Diana M. Sarmiento Páez, Raúl Romero Galindo, David A. Saucedo Alfonzo, Edgar O. López de León, Claudia Hernández Aguilar

Impact of COVID-19 in Mexico: A vision

the National Polytechnic Institute (Mexico), line of research in Engineering Systems, member of the transdisciplinary research group. Main contributions in ophthalmology and optometry with issues related to visual health care

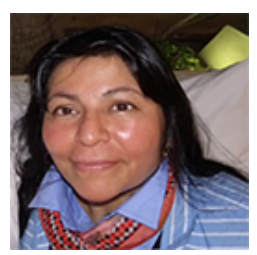

Dra. C. Hernández-Aguilar is a professor-researcher of the National Polytechnic Institute, within the Graduate Program in Systems Engineering of ESIME-Zacatenco. Member of the Mexican Academy of Sciences and the National System of Researchers (México). International distinction as member of the Editorial Committee of the journal: International Agrophysics (period:2012-present). Coordinator of the graduate programs in systems engineering (period 2012-2017). Creator and leader of the research group on Biophysical Systems for Agriculture, Food and Medicine with a Transdisciplinary approach. Main contributions related to methods for improvement and quality evaluation of agricultural seeds and food. Among other methods: laser radiation, electromagnetic field (fixed and variable), ultraviolet radiation (A-B-C), infrared, LED diodes, ozone, natural. In addition, the researcher proposes food products using nutraceutical: turmeric bread, moringa, lentil sprouts, etc. Working to Create a culture for its consumption to improve the health of the population. Concerned and occupied in improving the quality of life of society. Trainer of researchers in the last 13 years, making a call to conscience, to rescue a human attitude in the research process and the impact obtained from it. Motto: Transform yourself, to transform your world. 